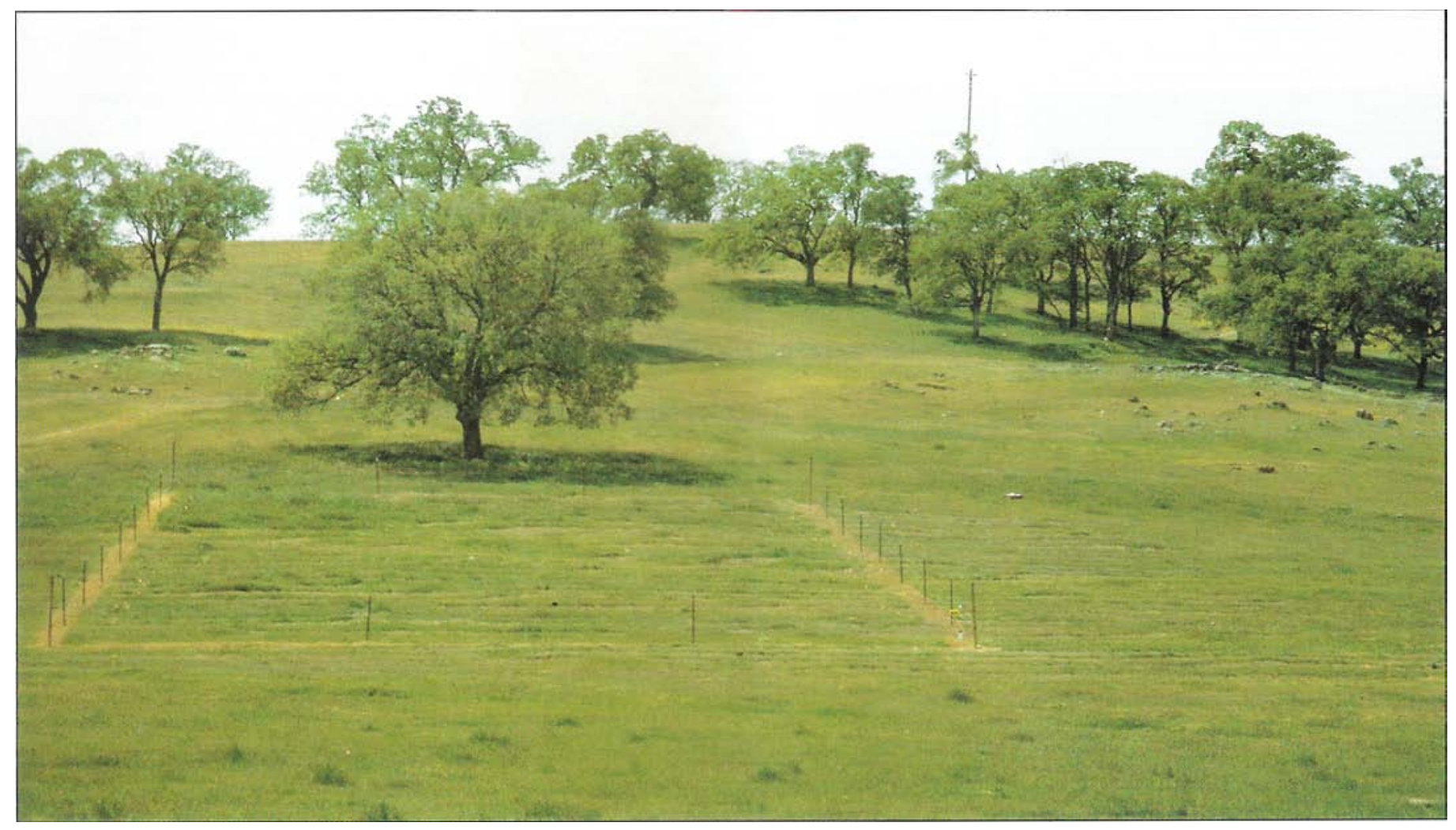

\title{
Preliminary study on harsh site offers hope for blue oak regeneration
}

\author{
Richard D. Standiford $\quad \square \quad$ Donald L. Appleton
}

\section{Blue oaks were planted on a Tuolumne County hardwood rangeland site to assess low-input, low-cost regeneration technology on seedling establishment. After three growing seasons, approxi- mately $22 \%$ of the planting spots had a surviving seedling. Costs ranged from $\$ 1.88$ to $\$ 32.58$ per surviving tree.}

Sustainable management of California's hardwood rangelands for wildlife habitat, livestock grazing, wood products and aesthetics requires establishing a sufficient number of oak seedlings and saplings to replace trees as they die. Statewide regeneration surveys of blue oak (Quercus

douglasii H. \& A.), the most widely distributed oak species on the state's hardwood rangelands, show the mature trees that die on some sites are replaced by inadequate numbers of naturally occurring seedlings and saplings. This is especially true on harsh sites characterized by low rainfall and droughty soils.

Low soil moisture often limits successful blue oak seedling and sapling establishment. Research by the University of California's Integrated Hardwood Range Management Program shows that controlling annual vegetation around a developing seedling often reduces competition for soil moisture enough to allow the seedling to grow. Although irrigation improves seedling survival and early tree growth, its high cost and the low supply of available water on hardwood rangelands limit its usefulness. Depredation of acorns and seedlings by wildlife, insects, diseases and livestock also defeat regeneration. The protective devices that have been used usually require regular field inspection and are expensive.

Where natural blue oak regeneration is poor, tree planting may ensure sufficient seedlings and saplings to sustain oak cover. Interest in oak habitat restoration has also created an interest in planting. County and city planners have created a demand for oak regeneration technology by requiring mitigation of urban development effects on hardwood rangelands. To date, most oak planting studies on hardwood rangelands have relied on costly, high-input management practices characterized by permanent irrigation systems, mechanical augering and expensive protection devices. These are often impractical for large-scale projects. There has also been a paucity of research studies on droughty, shallow soil types.

In this study, planting of oak seedlings and acorns was field-tested on a harsh range site, using low-input technology that called for visits two or three times during their establishment.

\section{Planting site}

Located on property of the La Ventana Land and Cattle Company in Tuolumne County near La Grange, the study site was adjacent to Lake Don Pedro's southern 
shore, at an elevation of 980 feet. Longterm annual rainfall averages 19.8 inches at Lake Don Pedro Dam, about 1 mile from the planting site and at a similar elevation. During this study, rainfall was 18.0 inches for the 1989-90 season and 14.0 inches during 1990-91, representing 90 and $70 \%$, respectively, of normal rainfall. The site's general vegetation was a mixture of blue oak woodland with a crown canopy of 10 to $25 \%$ and open annual grasslands. The area's soils were in the Auburn/Argonaut complex and were 14 to 30 inches deep with a slow rate of water percolation. Slope was less than $10 \%$. The study area was mainly used for cattle grazing. A cattle watering area and supplemental feeding station were located within 100 feet of the study site, which resulted in a seasonally high cattle concentration. During this study, cattle grazing occurred only from November through April. Overall cattle use for the 38-acre pasture under study ranged from 5 to 20 cows. Pocket gophers (Thomomys bottae Eydoux \& Gervais) and ground squirrels

(Spermophilus beecheyi Richardson) were abundant.

\section{Study design and treatments}

We chose a factorial experimental design to evaluate the effect of two levels of four different planting factors and the interaction between factors. There were three replications, creating a total of 48 blocks in the study $(2 \times 2 \times 2 \times 2 \times 3=48$ blocks). Two blocks were lost in the course of the study, reducing the total to 46 . The four factors evaluated are described below. Each replication contained 10 planting spots at an 8-foot spacing for 460 planting locations in the study. The study area covered 0.7 acre. Treatments were randomly assigned.

Fencing. Fenced and unfenced treatments were included to evaluate the impact of livestock exclusion on oak seedling survival. In the fenced area, a three-strand electric fence was used because of its ease in setting up and low cost. Total cost for all fencing materials was $\$ 160$ for a third of an acre. Because the fence charger and other fixed costs could be used for a much larger area, fencing costs are expected to be less than $\$ 100$ per fenced acre. The unfenced area was accessible to cattle grazing during the study.

Irrigation. Both irrigated and unirrigated areas were included. Irrigation involved hand-watering each planting spot once a month in June, July and August of 1990 at the rate of 1 gallon of water per spot. This treatment simulated use of a watering truck where installation of a permanent irrigation system was impractical. No irrigation was applied after the first year.
Augering. Oak seedlings are noted for their capacity to grow deep tap roots. Previous studies have used preplanting augering to enhance deeper root penetration. A gasoline-powered hand auger was used to drill holes about 1 foot deep and the holes were back-filled before planting. Deeper holes could not be dug because of the planting site's dense clay layer and high rock content. A nonaugered control was included.

Seedling stock type. Both directseeded acorns and 4-month-old containergrown seedlings were utilized. Acorns for both direct seeding and for container stock were collected directly from trees at the planting site to ensure local adaptability. Low-quality acorns were discarded; those remaining were refrigerated in plastic bags. Direct-seeded acorns were fieldplanted approximately 1 inch below the ground on November 21, 1989, with a hand trowel. Seedlings were grown at the
Dewitt Nelson Center by a California Youth Authority horticulture class. Acorns were sown in 50-cubic-inch "Ray Leach Tubes" and grown in the greenhouse for 4 months. Seedlings were then hardened off in a lath house before field-planting during the first 2 weeks of April 1990. Soils at the study site were at full moisture capacity in the root zone at the time of seedling planting.

\section{Methods}

The entire area was treated to overcome the well-documented deleterious effect of annual grass competition and pocket gophers. A $1 \%$ glyphosate treatment was sprayed in 3-foot-wide strips on the entire study area each spring. Pocket gophers were treated during the first year with strychnine-coated grain.

Each planting spot was evaluated approximately once a month during the first three growing seasons (March to Septem-
TABLE 1. Yearly trend in spring survival of blue oak seedlings for four different treatments

\begin{tabular}{|c|c|c|c|c|}
\hline & & \multicolumn{3}{|c|}{ Percent of trees with green leaves } \\
\hline \multicolumn{2}{|c|}{ Treatments } & June 15, 1990 & May 15,1991 & June 17,1992 \\
\hline \multirow{3}{*}{ Fencing } & Unfenced & 43.2 & 40.5 & 25.0 \\
\hline & Fenced & 38.8 & 35.8 & 18.8 \\
\hline & Significance* ${ }^{*}$ & $(0.33)$ & $(0.31)$ & $(0.10)$ \\
\hline \multirow[t]{3}{*}{ Irrigation } & Unirrigated & 37.7 & 33.6 & 17.3 \\
\hline & Irrigated & 44.2 & 42.1 & 25.8 \\
\hline & Significance* & $(0.13)$ & $(0.06)$ & $(0.03)$ \\
\hline \multirow{3}{*}{ Auger } & Non-augered & 50.4 & 36.5 & 18.7 \\
\hline & Augered & 31.3 & 39.6 & 24.8 \\
\hline & Significance* & $(0.001)$ & $(0.50)$ & $(0.11)$ \\
\hline \multirow{3}{*}{ Stock type } & Acorn & 47.0 & 38.7 & 21.3 \\
\hline & Seedling & 34.8 & 37.4 & 22.2 \\
\hline & Significance $^{\star}$ & $(0.01)$ & $(0.77)$ & $(0.82)$ \\
\hline \multicolumn{2}{|c|}{ Totals - all treatments } & 40.9 & 38.0 & 21.7 \\
\hline
\end{tabular}

*Statistical significance was analyzed using chi-square. The lower the probability level shown in parentheses, the higher the statistical significance of the treatments.

TABLE 2. Third-year survival of blue oak seedlings planted at 680 trees per acre and total establishment costs per acre and per surviving tree

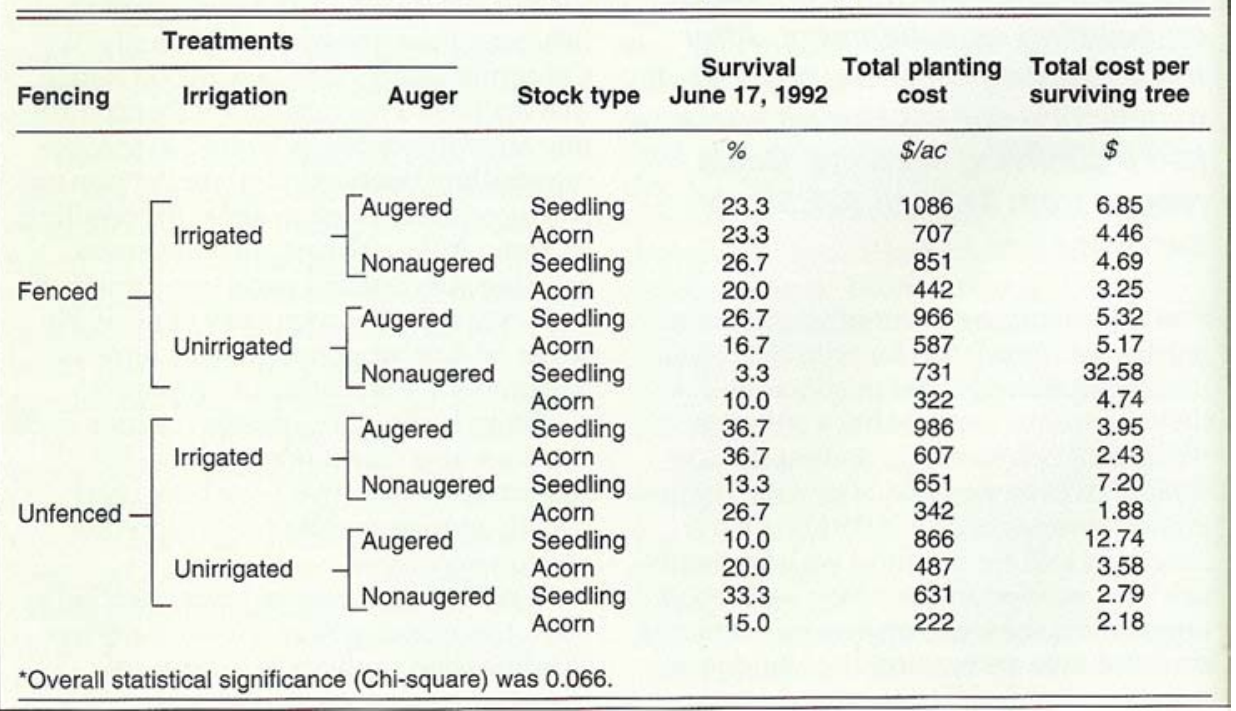



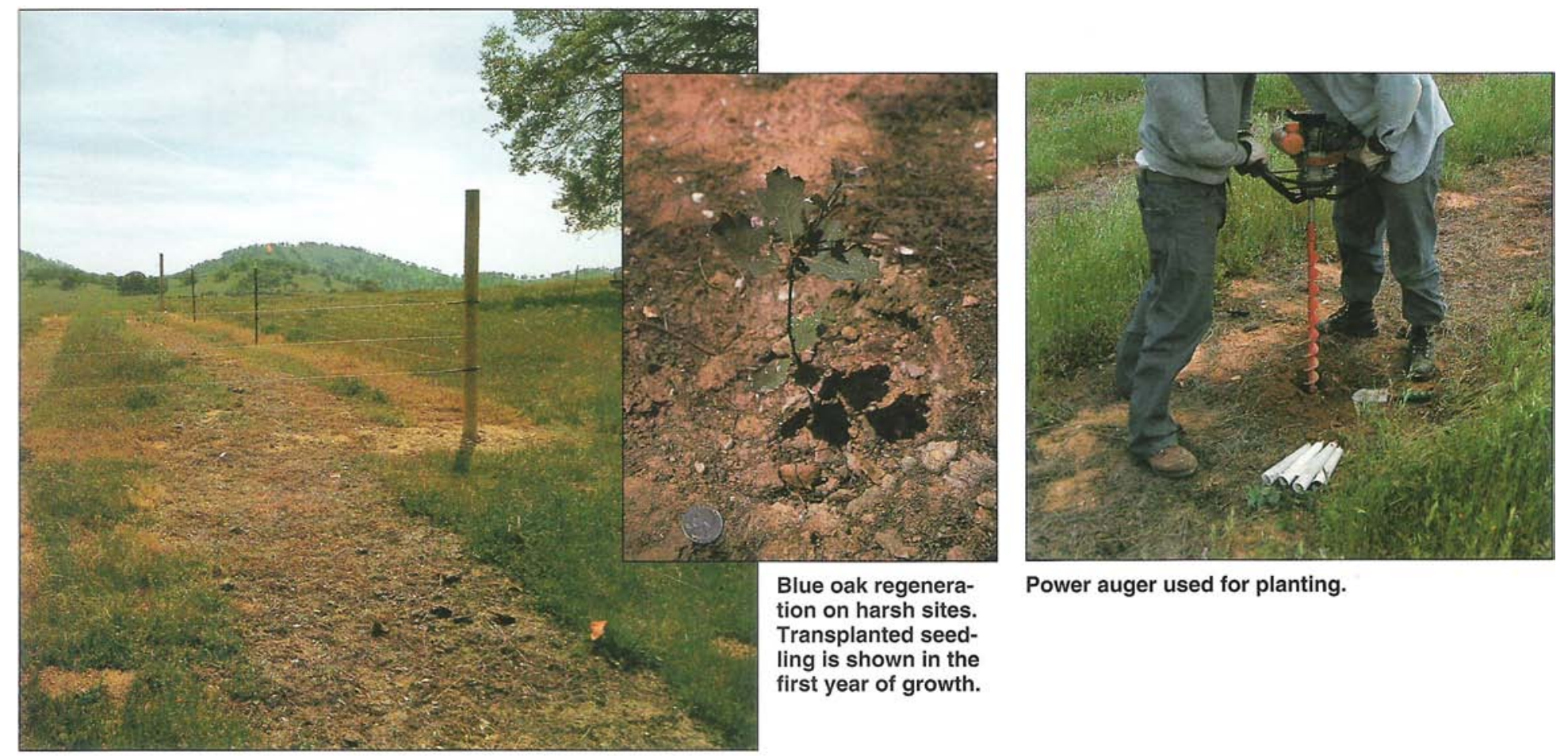

Power auger used for planting.

Treatments, fenced and unfenced. Note weed control strips.

ber) to determine whether a "living" seedling was present. Seedlings were considered "living" if green leaves were present. Most seedlings died back to ground level by late summer and resprouted in spring as a result of the drought and high levels of herbivory by grasshoppers, rodents and cattle. Therefore, no data on tree height or diameter were taken. These will be evaluated in the future.

Because seedling survival was denoted as present or absent, a chi-square analysis was conducted to evaluate the statistical significance of each planting factor.

\section{Results}

Figure 1 shows the trend of acorn emergence and seedling survival over the 30-month study. A major grasshopper infestation in early July 1990 resulted in heavy losses because screen protectors were not used due to their high cost. In addition to consuming the foliage, grasshoppers often completely girdled the young oak stems. Many seedlings resprouted later that year and the following spring, so survival for both seedlings and direct-seeded acorns in spring of 1991 was close to $40 \%$. By June 1992, additional grasshopper attacks and drought effects reduced survival to approximately $22 \%$. Because low survival is at least partially due to [[OK?]] drought-induced leaf fall, it will be useful to reevaluate the seedlings for several more seasons to see how many seedlings actually become established.
Table 1 shows the chi-square analysis of spring survival data for the three growing seasons. In the first year (June 15, 1990), both augering and stock type had a statistically significant effect on spring survival, with the nonaugered blocks having almost a $20 \%$ higher survival than augered blocks. This effect was not significant after the first season. Seedlings derived from direct-seeded acorns had a significantly higher survival than container seedlings in the first season; this also was less significant by the second and third seasons. Effects of the first-year irrigation had become increasingly apparent over time. Survival in the late spring of the third growing season (June 17, 1992) was significantly higher in blocks that had received first-year irrigation than in the unirrigated blocks (26 versus 17\%). This may be because irrigation resulted in a better-developed root system and a superior capacity for resprouting in subsequent years.

Table 2 shows a detailed comparison of each of the 16 combinations of planting factors on third-year survival. These treatment effects are significant at the 0.066 level. The highest survival was for the unfenced, irrigated, augered blocks. Both acorns and container seedlings had almost a $37 \%$ survival. The lowest survival was the fenced, unirrigated, nonaugered seedling blocks, with $3.3 \%$ survival.

Table 2 also provides a general approximation of costs per acre for the different treatments. These costs are derived from general information in the literature, as well as from estimates of what actual costs might be in an operational rather than an experimental planting. Costs ranged from $\$ 222$ per acre for acorn planting without fencing, augering or hand-watering to $\$ 1,086$ per acre for seedling planting with fencing, augering and irrigation. This fivefold cost difference provides motivation for evaluating the success for each factor. When per-acre costs are combined with survival data, the costs can be expressed on a per-surviving-tree basis, ranging from a high of $\$ 32.58$ per tree for fenced, unirrigated, nonaugered seedling

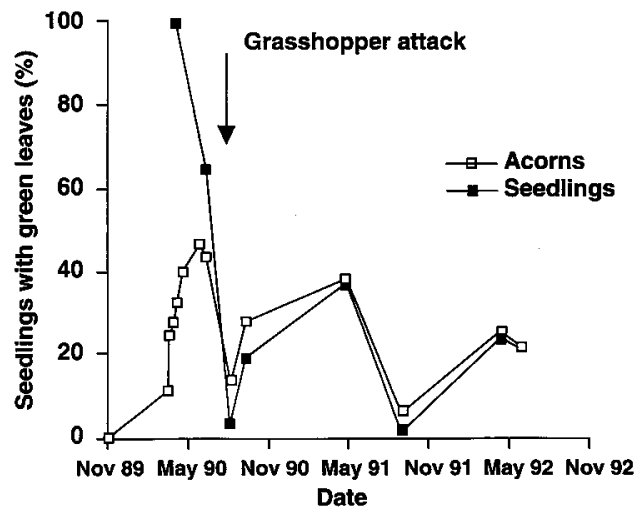

Fig. 1. Trend in the percentage of planted blue oak seedlings with green leaves for direct-seeded acorns and container seedlings during 31 months after planting. 
blocks to a low of $\$ 1.88$ per surviving tree for unfenced, irrigated, nonaugered directseeded acorns. (Since figures are developed on a per-surviving-tree basis, and there are more surviving trees in the irrigated treatment, the cost per surviving tree decreases.)

\section{Conclusions}

Blue oaks have a remarkable capacity to persist on harsh sites in droughts, as shown by fluctuations in the apparent survival curves in figure 1 . These are preliminary results; it is still unknown what longterm survival and tree growth responses will be. Interestingly, the only significant effect on surviving seedlings in the third growing season came from irrigation. These effects will continue to be monitored for several years to ascertain whether any of these treatments can be used for successful low-cost regeneration of blue oaks on hardwood rangelands.

The decision to not include seedling protectors in this study because of their high cost ( $\$ 2$ to $\$ 8$ per protector) undoubtedly increased grasshopper damage. A new study was initiated at this site in the winter of 1991-92 to directly evaluate the cost-effectiveness of different seedling protectors versus an unprotected control.

The overall impression of the costly augering treatment after 3 years is that this may not be a useful cultural tool. Acorns also appear to be a more cost-effective source of plant material than seedlings on these low-quality rangeland sites.

More than $80 \%$ of California's hardwood rangelands are privately owned, making results of studies such as this extremely important, since adoption of oak regeneration technology by landowners will be largely dictated by its cost. This current study is designed to follow the long-term survival and growth of blue oaks under treatments that simulate a planting operation which requires only two or three visits for cultural treatments (irrigation, weed control, planting) during the establishment period. Based on 30 months of survival data, it may be possible to establish 180 to 250 oak seedlings per acre at a cost of $\$ 300$ to $\$ 500$ per acre, although their growth and continued survival will be monitored to refine these conclusions.

\footnotetext{
R. B. Standiford is Forest Management Specialist, UC Berkeley, and D. L. Appleton is Farm Advisor and County Director, Tuolumne County Cooperative Extension.

The authors wish to thank Bill and Don Beck of the La Ventana Land and Cattle Company for their assistance, and the students at the DeWitt Nelson Center horticulture class for growing and planting the seedlings.
}

\title{
Farmers increase hiring through labor contractors
}

\author{
Philip L. Martin $\quad$ Gregory P. Miller

\section{Labor costs are down, but contractor abuses are rising.}

\begin{abstract}
Farm wages in California, as a percentage of farm sales, fell slightly during the 1980s, partly because many farmers switched to hiring workers through Farm Labor Contractors (FLCs). The abuses frequently attributed to FLCs - including underpayment or nonpayment of wages and (over)charges for housing, transportation and work equipment have renewed legislative interest in regulating their activities.
\end{abstract}

California, the nation's major farm state, accounts for $11 \%$ of annual U.S. farm sales and $24 \%$ of U.S. farm labor expenditures. California agriculture specializes in producing fruits and nuts, vegetables and melons, and horticultural specialties, such as flowers, nursery products and mushrooms; the state's fruit, vegetable and horticulture (FVH) sales are $36 \%$ of the U.S. total, and in the 1987 Census of Agriculture, California FVH farms accounted for $43 \%$ of the labor expenditures of such farms.

Reviewed here are trends in California farm employment and wages between 1984 and 1990 . These were the years immediately before and after the decade's major change in immigration law: enactment of the Immigration Reform and Control Act (IRCA) of 1986 to reduce illegal immigration. Previous studies examined how farmers responded to IRCA on the basis of grower surveys (California Agriculture, January-February 1990); this study is based on the statewide wage and employee data that California farmers report with their Unemployment Insurance (UI) taxes. Because California requires all employers who pay $\$ 100$ or more in wages to file UI reports listing the names and social security numbers of their employees, these data should be a virtual census of all persons employed on California farms during these years.

\section{IRCA and California agriculture}

The legislation that eventually became IRCA began as proposals for (1) sanctions or fines on employers who knowingly hired illegal alien workers and (2) legalization for aliens who had established themselves in the United States. There were initially no special provisions in the proposed legislation for agriculture but, as prospects for immigration reform legislation improved in the early 1980s, California farmers led an ultimately successful fight to add a third pillar to IRCA. California farmers argued that the existing nonimmigrant or $\mathrm{H}-2$ program, through which foreign farmworkers could legally be brought to the U.S., was not workable in California. Instead, they pushed for a "free agent" program that would restrict foreign workers to agricultural employment, but would permit them to migrate from farm to farm.

Congress ultimately rejected this California farmer proposal for free agent foreign workers, but IRCA included a Special Agricultural Worker (SAW) program through which unauthorized workers who had done at least 90 days of qualifying farm work in the 12 months ending May 1, 1986, could become temporary and eventually permanent U.S. residents and workers. More than half of the 1.3 million SAW applications were filed in California, equivalent to three-fourths of the 1 million workers typically reported by the state's farmers to the UI system each year.

IRCA was widely expected to require farmers to adjust to a new era of legal and more settled and stable farmworkers. If the workers were freer to change jobs, one 